\title{
Immunohistochemistry and Hormonal Investigation for Spermatogenesis Restoration in Degenerated Testes of Rats after Bone Marrow Stem Cells Transplantation
}

\author{
Ahmed M. Mousbah $^{1 *}$; Mohamed E. Abd El-Samie ${ }^{2}$; Mohamed A. Elbehery ${ }^{1}$; and Ismail, A. El-Nady ${ }^{3}$ \\ ${ }^{1}$ Department of Biotechnology, Faculty of Agriculture, Cairo, Al-Azhar University, Egypt. \\ ${ }^{2}$ Department of Chemistry, Animal Health Research Institute, Dokki, Giza, Egypt. \\ ${ }^{3}$ Animal Production Department, Faculty of Agriculture, Cairo, Al-Azhar University, Egypt. \\ *Corresponding Author, Ahmed M. Mousbah, E-Mail: mousbah.biotech2012@ gmail.com
}

\begin{abstract}
Stem cell therapy is considered an important and innovative tool for applied research in andrology, especially in infertility; therefore, it was later adapted as potential therapeutic agents. This study aimed to evaluate rat mononuclear bone marrow cells' ability to recover testis cells in cyclophosphamide (CTX)-treated rats and to assess its effects on hormonal and histopathological changes. The bone marrow cells were harvested from femurs and tibias of rats and purified by a Histopaque gradient. Mononuclear bone marrow cells transplantation was performed by intravenous injection of cells in cyclophosphamide-treated animals. Three weeks after transplantation, blood samples were collected and analyzed for hormonal assay. In addition, the testes were collected for histological and histopathological determination. The results depicted that the serum levels of all tested hormones were significantly different among the three experimental groups G1 (control, healthy animals), G2 (CTX induced infertility and untreated) and G3 (CTX induced infertility and treated with stem cells). FSH and LH levels were significantly increased in G2 (CTX) compared to G1 and G3. Total and free testosterone levels were slightly higher in G3 compared to G2. Mononuclear bone marrow cell transplantation promoted cellular reorganization of the seminiferous epithelium. Also, spermatogenesis regeneration was improved. In conclusion, bone marrow stem cells can regenerate the damaged testicular elements and hence restore hormonal regulation in cyclophosphamide treated rat. Therefore, the treatment of male infertility and testosterone deficiency could be therapeutically treated by using stem cells.
\end{abstract}

Keywords: Cyclophosphamide, Infertility, Spermatogenesis, Stem Cells, Testes.

\section{INTRODUCTION}

Infertility is a significant health and social problem. Previous studies have reported that approximately $70-90 \%$ of human infertility is related to spermatogenesis defects (Aliakbari et al., 2016). Also, chemotherapy is associated with impaired spermatogenesis, azoospermia and male infertility (Drumond et al.,. 2011; Comish et al., 2014; Zhu et al., 2015). In recent years, more attention has been centralized on stem cell therapy for infertility (Peak $\boldsymbol{e t}$ al., 2016; Kadam et al., 2017; Pourmoghadam et al., 2018; Fazeli et al., 2018). The testicular function is influenced by hormones to regulate spermatogenesis (McLachlan et al., 2002). Testosterone directs spermatogenesis in males and its absence or the

\section{Original Article:}

DOI:https://dx.doi.org/10.21608/javs. $\underline{2020.118002}$

Received :29 June, 2020.
Accepted :15 Sept., 2020.
Published in October, 2020.

This is an open access article under the term of the Creative Commons Attribution 4.0 (CC-BY) International License . To view a copy of this license, visit http://creativecommons.org/licenses/by/4.0/

\section{J. Appl. Vet. Sci., 5(4): $47-54$.}

androgen receptor, spermatogenesis does not pass the meiosis stage (Walker, 2011). Luteinizing Hormone (LH) mainly functions to stimulate testosterone emission from the testicle's Leydig cells, while Follicle Stimulating Hormone (FSH) stimulates Sertoli cells to facilitate germ cell differentiation (Weinbauer $\boldsymbol{e t}$ al., 2010\& O'Shaughnessy, 2014).

Cyclophosphamide (CTX) is an anticancer drug with mutagenic and cytotoxic effects mainly used in males because it causes testes castration as azoospermia and seminiferous tubular atrophy (Emadi et al., 2009; Drumond et al.., 2011; Comish et al., 2014). Cyclophosphamide affects the spermatogenesis process via direct damage of DNA and RNA as well as the induction of apoptosis, in addition, disrupting 
protein expression of Sertoli cells (Drumond $\boldsymbol{e t}$ al., 2011; Bakhtiary et al., 2014; Aliakbari et al., 2016; Cao et al., 2017). Cyclophosphamide increases FSH and LH hormone levels compared to standard levels (Babu et al., 2004) and decreases testosterone hormone levels (Zhu et al., 2015).

Stem cells are biological and undifferentiated cells with the ability to proliferate and differentiate into specialized cells found in multicellular organisms and mammals (Spradling et al., 2001). Stem cells have the potentiality to self-renew and develop into many different types of cells in the body. They serve as a repair system for the body (Kørbling and Estrov, 2003). Bone marrow is a well-accepted source of various adult stem cells such as hematopoietic stem cells (HSCs), mesenchymal stem cells (MSCs) and multipotential adult progenitor cells (Nayernia et al., 2006; Drusenheimer et al., 2007 and Hwang et al., 2009).

Previous studies have found that human bone marrow cells can differentiate to putative male germ cells, Sertoli cells and Leydig cells (Nayernia et al., 2006; Yazawa et al., 2006; Drusenheimer et al., 2007; Lue et al., 2007; Hou et al., 2016). Furthermore, the Researcher identified bone marrow as a potential source of male germ cells that could sustain sperm production and regenerate spermatogenesis (Cakici $\boldsymbol{e t}$ al., 2013; Monsefi et al., 2013; Zhang et al., 2014).

Testis harbors two stem cell types, the multipotent mesenchymal stem cells and the unipotent spermatogonial stem cells (SSCs) (Ebata et al., 2008). In vivo, SSCs involve in regeneration and maintenance of spermatogenesis (Ebata et al., 2011; Cakici et al., .2013). Promising studies have shown that stem cells positively affect the reconstruction of testicular germinal epithelium in infertile male animals and restore fertility. Stem cells might have functioned in the reestablishment of spermatogenesis by two ways: maintaining the preexisting spermatogonial stem cells (SSCs) or by transdifferentiation into SSC-like cells to form spermatocytes (Cakici et al., 2013; Monsefi $\boldsymbol{e t}$ al.,. 2013; Zhang et al., 2014; Tamadon et al., 2015; Ghasemzadeh-Hasankolaei et al., 2016).

This work's initial hypothesis is about mononuclear stem cells' ability derived from bone marrow to restore the spermatogenesis at the degenerated testes. Considering that, we propose evaluating the ability of mononuclear bone marrow cells (containing hematopoietic and mesenchymal stem cells) to promote testicular functions in cyclophosphamide-treated rats and evaluated by hormonal assay and histopathology.

\section{MATERIAL AND METHODS}

\section{1- Experimental Animal Model}

Forty adult male Wistar (Rattus norvegicus Albinus) rats age ranged 7-8 weeks old, weighing (135$150 \mathrm{~g}$ ), purchased from Holding Company for Biological Products and Vaccines (Vacsera), Helwan, Egypt. Rats were housed at the animal house of the Animal Production Department, Faculty of Agriculture, Al-Azhar University, Cairo, Egypt in steel mesh cage (5 rats/cage) and maintained for two weeks acclimatization period on standard commercial diet and tap water in the animal house and subjected to a 12:12 $\mathrm{h}$ daylight/darkness and allowed unlimited access to chow and water at summer season. All ethical protocols for animal treatment were followed and supervised according to standard protocols (NIH Publication No. 85-23, revised 1996).

Animals were divided randomly into four groups (10 rats each). Group1, control (healthy animals), group 2 including rats induced with testis damage untreated, injected with cyclophosphamide (CTX), group 3 including Rats induce by testis failure using CTX treated with stem cells and group 4 for bone marrow MSCs donation. Cyclophosphamide (CTX) was injected intraperitoneally (IP) at the level of a loading dose $(50 \mathrm{mg} / \mathrm{kg})$ for one day and rotating dose $8 \mathrm{mg} / \mathrm{kg}$ body weight into two weeks by Endoxan $1 \mathrm{~g}$ (Baxter Co.), which was dissolved in PBS (Freireich et al., 1986; Neosar, 2013).

\section{2 - Obtaining Rat Bone Marrow `Stem Cells}

\section{1- Isolation and Purification of Mononuclear Bone} Marrow Cells

According to Snykers et al. (2006), the rats were sacrificed after anesthesia with diethyl ether (Sigma-Aldrich Co. LLC). Then, the femur and tibia were separated. The bone marrow cells were harvested from femurs and tibias of rats and purified by Histopaque-1077 gradient (Sigma Aldrich) (Snykers et al., 2006). The viable (white) and dead (blue) cells were counted in the hemocytometer under a light microscope. Only cell suspensions with a $90 \%$ viability or greater were used (Bazhanov et al., 2016).

\section{2- Stem cell transplantation}

Immediately after the last injection of CTX, the rats in (G3) were injected daily for three days with stem cells (SCs) at a dose (BMSCs, 5x10 $0^{6}$ cells $/ 40 \mu \mathrm{l}$ ) dissolved in a $40-\mu \mathrm{L}$ volume of PBS. On the first day, the rats were injected Intravenously (G3) in the tail's vein with one dose of SCs. Then, the rats were injected with two doses of SCs intravenously and intraperitoneally on the second day. Finally, on the third day, the rats injected with two doses of SCs intravenously and subcutaneously (Meyerrose et al., 2007; Wilson et al., 2010; Eliopoulos et al., 2010; Yousefi et al., 2013). 


\section{Hormonal Assessment}

After three weeks of the last injection with CTX, all rats were sacrificed by anesthesia with diethyl ether. The blood was collected before euthanasia from the caudal vein and eyes by capillary tubes from all rat groups. Serum was separated and stored at $-08^{\circ} \mathrm{C}$ for enzyme immunoassays of FSH, LH, Testosterone total and testosterone free by Enzyme-Linked Immunosorbent Assay (ELISA). FSH was determined by Rat Follicle-Stimulating Hormone (FSH) ELISA Kit (SinoGene Clone Biotech Co.Ltd; Hangzhou, China, Catalogue Number: SG-20702). LH was determined by Rat luteotropic hormone (LH) ELISA kit (SinoGene Clone Biotech Co.Ltd; Hangzhou, China, Catalog No. SG-20701). Serum Concentrations of testosterone were measured using ELISA as described in the manufacturer's kit (DBC, Dignostic Biochem Canada Inc., Ontario, Canada; Catalog No. CAN-TE-250). According to (DBC, Diagnostic Biochem Canada Inc., Ontario, Canada; Catalog No. CAN-FTE-260), free testosterone ELISA was determined.

\section{Histological and Immunohistochemistry (IHC) examination}

Histological examination was performed according to Suvarna et al.., (2013) using Hematoxylin and Eosin (H\&E) staining. Further sections on positively charged coated slides were used for IHC technique using Abs marking the integrity state of testes component as following: First, Androgen Receptor Monoclonal Antibody (AR 441), from (Invitrogen, Thermo Fisher Scientifics, USA, Catalog \# MA5-13426). Second, Transforming growth factorbeta receptor III (TGF- $\beta$ R3), Polyclonal Antibody purchased from (Invitrogen, Thermo Fisher Scientifics, USA, Catalog \# PA5-17529). The third is the Connexin 43 Monoclonal Antibody (CX-1B1) from (Invitrogen, Thermo Fisher Scientifics, USA, Catalog \# 13-8300).

\section{Statistical Analysis}

All statistical analyses were conducted using oneway ANOVA with Dunnett's post-test using IBM SPSS statistics 20 software.

\section{RESULTS}

\section{Hormonal assay}

The serum levels of tested hormones were all significantly different among these three groups G1 (control), G2 (CTX induced infertility and untreated) and G3 (CTX induced infertility and treated with stem cells) (Table 1). FSH and LH levels were significantly increased in G2 (CTX) comparing with G1 and G3. While decreased in G3 compared with G2. Testosterone (total and free) levels were high significantly in G1 comparing with G2 and G3.
Table 1: Effect of cyclophosphamide and stem cells on serum concentration of FSH, LH and Testosterone (total and free) hormones of adult male rats

\begin{tabular}{|l|c|c|c|c|}
\hline Group & $\begin{array}{c}\text { FSH } \\
(\mathrm{ng} / \mathrm{L})\end{array}$ & $\begin{array}{c}\mathrm{LH} \\
(\mathrm{ng} / \mathrm{L})\end{array}$ & $\begin{array}{c}\text { Total } \\
\text { testosterone } \\
(\mathrm{ng} / \mathrm{ml})\end{array}$ & $\begin{array}{c}\text { Free } \\
\text { testosterone } \\
(\mathrm{pg} / \mathrm{ml})\end{array}$ \\
\hline G1 & 2.35 & 7.44 & 26.29 & 6.64 \\
$($ Control $)$ & \pm & \pm & \pm & \pm \\
& $0.24^{\mathrm{b}}$ & $0.09^{\mathrm{b}}$ & $4.80^{\mathrm{a}}$ & $1.45^{\mathrm{a}}$ \\
\hline G2 (CTX) & 3.13 & 15.69 & 6.48 & 1.32 \\
& \pm & \pm & \pm & \pm \\
& $0.30^{\mathrm{a}}$ & $0.29^{\mathrm{a}}$ & $1.71^{\mathrm{b}}$ & $0.21^{\mathrm{b}}$ \\
\hline G3 (CTX & 2.25 & 5.06 & 7.56 & 1.69 \\
$\&$ Stem & \pm & \pm & \pm & \pm \\
cell) & $0.23^{\mathrm{b}}$ & $0.05^{\mathrm{c}}$ & $1.95^{\mathrm{b}}$ & $0.30^{\mathrm{b}}$ \\
\hline P-Value & 0.0553 & 0.0001 & 0.0002 & 0.0003 \\
\hline
\end{tabular}

a-c: Means with the different superscripts in the same column differ significantly $(\mathrm{p}<0.05)$. Sig: significant. * :( $\mathrm{P}<0.05) * * *:(\mathrm{P}<0.01)$

FSH: Follicle Stimulating Hormone \& LH: Luteinizing Hormone

\section{Testicular Histological Observation}

The control G1 sections showed a normal seminiferous tubule. G2 histology showed effects of cyclophosphamide on the rat testis in the form of abnormal seminiferous tubules with a little quantity of germinal cells that showed a significant decrease in primary and secondary spermatocytes addition to spermatid and spermatozoa germinal cells. G3 showed the histological effects of stem cells on the rat testis in the form of a significant increase in primary and secondary spermatocytes and spermatid and spermatozoa germinal cells in the G3 group compared with G2. It quite resembled the G1 group (Fig.1).

\section{Testicular Immunohistochemistry Observation \\ 3.1. Androgen receptors (AR) Marker}

Androgen receptor expression revealed marked reactivity to AR - Ab in Sertoli cells of control normal group (A), while complete absence of Sertoli cells reactivity to $\mathrm{AR}-\mathrm{Ab}$ in damaged group (B). In addition, re-expression and reactivity to $\mathrm{AR}$ were detected in the treated group (C), (Fig.2).

\subsection{Transforming growth factor-beta receptor 3 (TGF-ßR3) Marker}

TGF- $\beta$ revealed reactivity to TGF- $\beta$ - Ab in Sertoli cells of the normal control group and complete absence of Sertoli cells reactivity to TGF- $\beta$ - Ab in the damaged group. In contrast, marked re-expression and reactivity to TGF- $\beta$ were detected in the treated group (Fig. 3). 

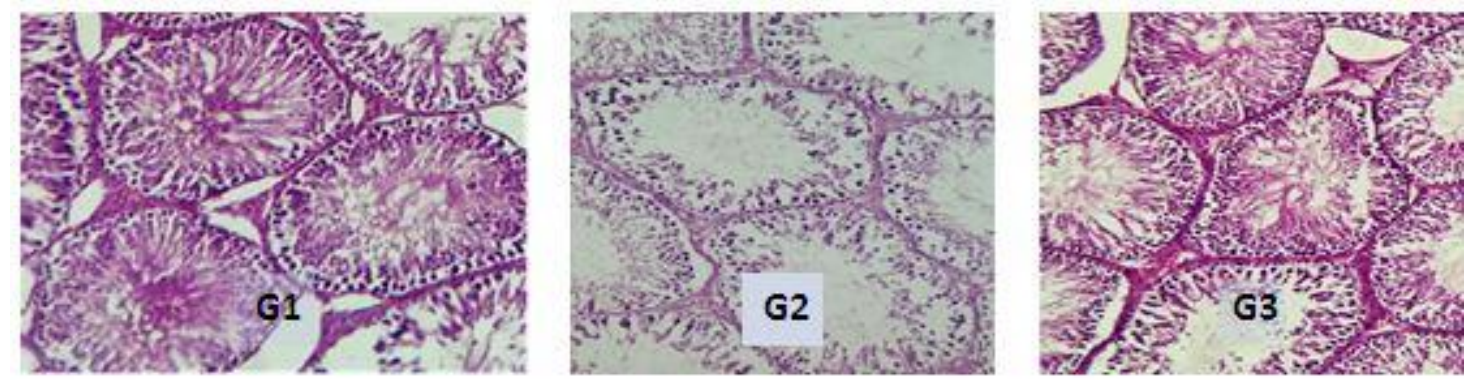

Fig. 1: Normal male testis (G1) control. Rat testis under the effect of cyclophosphamide (G2). Testis under the effect of stem cells (G3). (200x (H\&E stain)
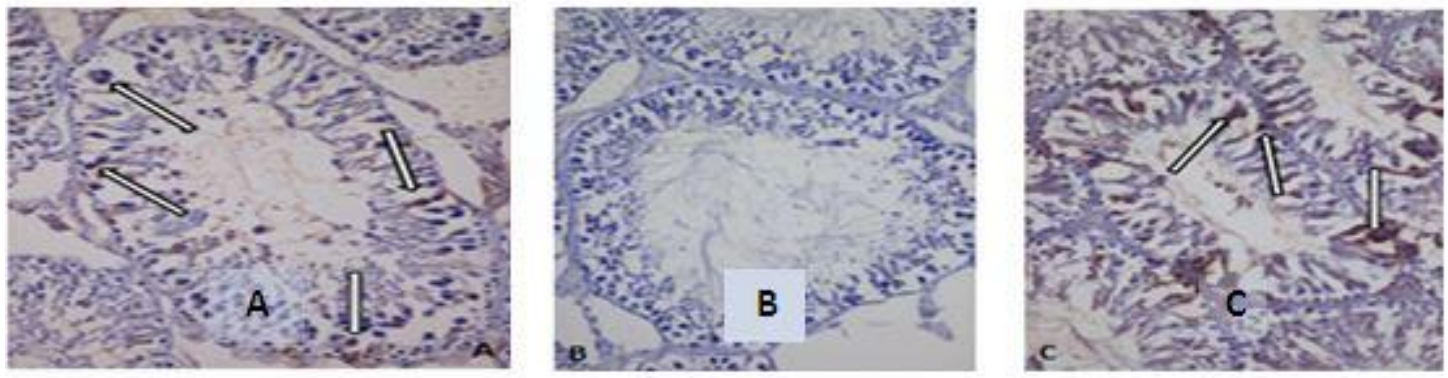

Fig. 2: (A) marked reactivity to AR - Ab in sertoli cells of control normal group. (B) Complete absence of sertoli cells reactivity to AR- $\mathrm{Ab}$ in damaged group. (C) re -expression and reactivity to AR treated group. (IHC/ AR- Ab X 400)
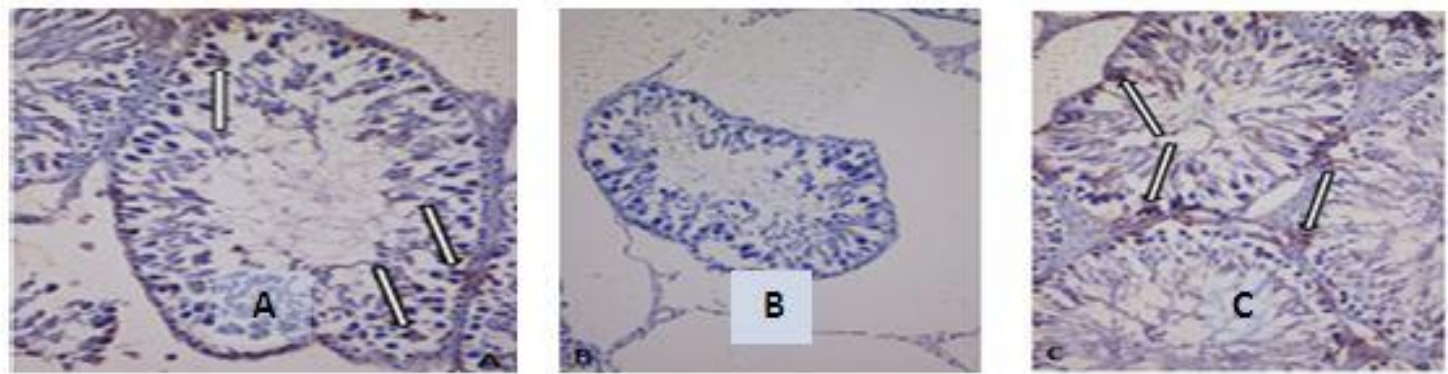

Fig. 3: (A) reactivity to TGF- $\beta$ - Ab in sertoli cells of control normal group. (B) Complete absence of sertoli cells reactivity to TGF- $\beta$ - Ab in damaged group. (C) marked re -expression and reactivity to TGF- $\beta$ in treated group (C). (IHC/ TGF- $\beta$ - Ab X 400)
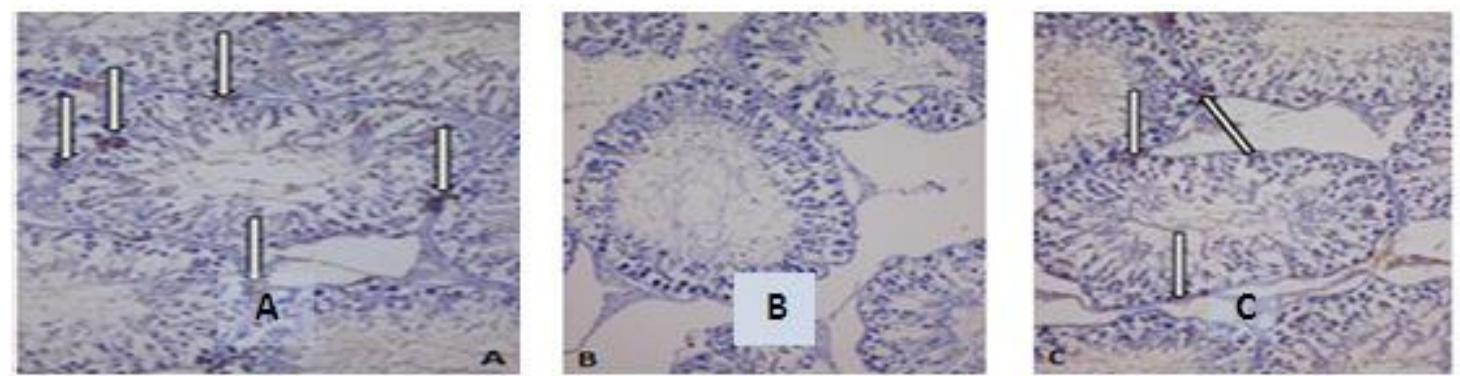

Fig. 4: (A) reactivity to $\mathrm{CX} 43 \mathrm{Ab}$ in some spermatogenic cells and some areas on seminiferous tubule walls in control normal group. (B) Complete absence of reactivity to $\mathrm{Cx} 43 \mathrm{Ab}$ in damaged group. (C) $\mathrm{Re}$-expression and reactivity to $\mathrm{Cx} 43$ in treated group. (IHC/ Cx43 - Ab X 400) 


\subsection{Connexin 43 (CX43) Marker}

Cx43 expression revealed reactivity to CX43 $\mathrm{Ab}$ in some spermatogenic cells and some areas on seminiferous tubule walls in the normal control group. A complete absence of reactivity to $\mathrm{Cx} 43 \mathrm{Ab}$ had been detected in the damaged group, while re-expression and reactivity to $\mathrm{Cx} 43$ were demonstrated in the treated group (Fig.4).

\section{DISCUSSION}

In this study, we were interested in male infertility therapy with stem cells from bone marrow in cyclophosphamide-induced in rats and evaluated by hormonal assay and histopathology. This study demonstrates that CTX adversely affected the hormonal levels associated with male spermatogenesis and induced histopathological alterations in the rat's testes. Stem cell repair system for the injured or damaged cells could be done through the following possibilities; first, researchers found that using specific induction condition, stem cells could differentiate into the target function cells; Second, stem cells transplantation is supporting other endogenous stem cells by secreting trophic factors to restore the injured host cell function. Third, stem cells fused or merged with the resident cells to recover the injured cell function (Kørbling and Estrov, 2003; Gnecchi and Melo, 2009; Song et al., 2011; Gou et al., 2012; Leatherman, 2013; Fazeli et al., 2018).

Regarding hormonal assays in our three study groups, increasing FSH and LH levels and decreasing the mean testosterone levels in G2 may be due to CTX. CTX is associated with oligozoospermia and azoospermia, increasing the level of FSH hormone compared by standard level in male rats (Howell $\boldsymbol{e t}$ al., 1999). A higher concentration of FSH and LH are considered to be a reliable indicator of germinal epithelial damage, disruption of testicular function and associated with azoospermia and severe oligozoospermia (Zabul et al., 1994; Weinbaurer and Nieschlag, 1995; Subhan et al., 1995; Babu et al., 2004; Zahkook et al., 2014). Furthermore, a decrease in the mean testosterone levels of cyclophosphamide treated mice served as proof for the damage of testis, and the inhibition of the spermatogenesis process (Elangovan et al., 2006) Also, increase in the apoptotic rate in the testis (Zhu et al., 2015).

Furthermore, decreasing of FSH and LH levels and slight increasing of testosterone in G3 may be due to treated with stem cells suggesting that SCs transplantation had a major impact in the restoration of normal structure and function of seminiferous tubule structure due to regeneration of somatic cellular component of the testis that respond to those hormones and secrete testosterone which in turn inhibits the secretion of FSH and $\mathrm{LH}$ and helps spermatogenesis and restore testicular function by improving seminiferous tubules and the hormonal profile (Peak $\boldsymbol{e t}$ al., 2016; Kadam et al., 2017; Pourmoghadam et al., 2018; Fazeli et al., 2018).

Regarding immunohistochemistry results, androgens are sexual hormones that had a critical role in normal reproductive organ development and functions (O'Hara and Smith, 2015). Androgen regulation of spermatogenesis is dependent upon action on the Sertoli cells (O'Shaughnessy, 2014). The impact of lacking AR in Sertoli cells mainly affects Sertoli cell functions to support and nurture germ cells, leading to spermatogenesis arrest at the diplotene primary spermatocyte stage prior to the first meiotic accomplishment division (Wang et al., 2009) that is matching our histopathological and immunehistochemistry results. In vivo evidence of the need for functional AR in Sertoli cells to maintain normal testosterone production and ensure normal male fertility (Chang, et al., 2004) explain our hormonal results in harmony with histological findings. Androgen/AR signaling in Sertoli cells plays an important role in spermatogenesis and Leydig cells play an autocrine regulatory role to modulate Leydig cell steroidogenic function (Tsai, et al., 2006).

TGF- $\beta$ R3 is an accessory receptor that binds to and modulates the activities of both transforming growth factor-beta (TGFbeta) and inhibin, two members of the TGFbeta superfamily of growth factors that regulate many aspects of reproductive biology with differential expression pattern, suggests divergent roles for this TGF- $\beta$ R3 in developing testis (Sarraj, et al., 2007). TGF- $\beta R 3$ is one of TGF $\beta$ signaling had a reflection in male genital abnormality (testicular dysgenesis) (Barthold, et al., 2015). It is required for normal cord formation, normal fetal Leydig cell development, and the establishment of fetal testis endocrine function (Sarraj, et al., 2010). Our investigation refers to partial restoration of TGF$\beta R 3$ in the testis of stem cell treated group which matching the hormonal analysis and detected previously by Goddard, et al,. (2000), who indicated to controlled effect on the steroidogenic activity of testicular Leydig cells by the pituitary hormone (LH) and by growth factors such as transforming growth factor-beta peptides.

Connexin 43 is a component of gap junctions, which allow for gap junction intercellular communication (GJIC) between cells to regulate cell death, proliferation, and differentiation (Cheng, et al., 2015) and in cases of impaired spermatogenesis, $\mathrm{Cx} 43$ expression has been shown to be altered 
in several mammals (Hollenbach, et al., 2018). The gap junction protein connexin43 (CX43) plays a vital role in mammalian spermatogenesis by allowing for direct cytoplasmic communication between neighbouring testicular cells. Different publications suggest that CX43 in Sertoli cells (SC) might be necessary for the blood-testis barrier (Gerber, et al., 2016). CX43 is essential for the cessation of proliferation and normal maturation in Sertoli cells. Also, CX43 in Sertoli cells is required for spermatogenesis (Sridharan, et al., 2007).

\section{CONCLUSIONS}

Finally, stem cells could protect the testis from damages caused by CTX and promote or protect the spermatogenesis from the present results. More studies are required in gametogenesis mechanisms, especially germ cell differentiation mechanisms, which would help design and establish a standard in vitro system for the production of germ cells from stem cells to treat male infertility. Further studies are needed in assessing the safety of stem cells transplantation in fertility recovery.

\section{ACKNOWLEDGMENT}

We would like to thank pDr. Naglaa Mohamed Elkalamawy, Dept. of histopathology, Animal Health Research Institute, Dokki, Giza, Egypt, for her kindness help regarding the histological and histochemistry examination this study.

\section{Conflict of Interest}

The authors declare no conflict of interest

\section{REFERENCES}

ALIAKBARI, F., YAZDEKHASTI, H., ABBASI, M., MONFARED, MH, BAAZM, M. 2016. Advances in Cryopreservation of Spermatogonial Stem Cells and Restoration of Male Fertility. Microscopy Res. And Tech. 79:122-129.

BAbU, S.R., SAGHNANI, M.D.,SWARANA, M., Padmavathi, P., REDDy, P.P. 2004. Evaluation of FSH, LH and Testosterone levels in different subgroups of infertile males. Indian J. Clin. Biochem., 19(1): 45-49.

Bakhtiary, Z., Shahrooz, R., Ahmadi, A., Zarei, L. 2014. Evaluation of antioxidant effects of crocin on sperm quality in cyclophosphamide treated adult mice. Vet. Res. Forum, 5:213-8

BARThOLd , J.S., WANG, Y., KolOn, T.F.Kollin, C., NordenskJöld, A., Olivant Fisher, A., et al., 2015. Phenotype specific association of the TGFBR3 locus with nonsyndromic cryptorchidism. J. Urol., 193(5): 163.

BAZHANOV, N., YLOSTALO, JH，BARTOSH，TJ, TIBLOW, A., MOHAMMADIPOOR, A., FOSKETT, A., PROCKOP, DJ 2016 .
Intraperitoneally infused human mesenchymal stem cells form aggregates with mouse immune cells and attach to peritoneal organs. Stem cell research \& therapy, 7(1): 27.

CAKICI， C., BUYRUKCU， B., DURUKSU， G., HALILOGLU, AH, AKSOY, A., ISIK, A., et al., 2013. Recovery of fertility in azoospermia rats after injection of adipose-tissue-derived mesenchymal stem cells: The sperm generation. BioMed Res. Int., (21) 529589

CaO, Y., WAng, X., LI, S., Wang, H., Yu, L., WANG, P. 2017. The Effects of 1-Carnitine Against Cyclophosphamide-Induced Injuries in Mouse Testis. Basic \& Clin. Pharmacol. \& toxicol., 120(2): 152-158.

Chang , C., Chen, Y.T., Yeh, S.D., Xu, Q., Wang, R.S., GuILlOU, F., LARDY, H., YEH, S. 2004. Infertility with defective spermatogenesis and hypotestosteronemia in male mice lacking the androgen receptor in Sertoli cells. Proc. Natl. Acad. Sci. USA, 4, 101(18): 6876-81.

Cheng , J.C., Chang, H.M., FAng, L., Sun, Y.P., Leung, P.C. 2015. TGF- $\beta 1$ up-regulates connexin 43 expression: a potential mechanism for human trophoblast cell differentiation. J. of Cellular Physiology, 230 (7): 1558-1566.

Comish, PB, Drumond, A.L., Kinnell, H.L., et Al., 2014. Fetal cyclophosphamide exposure induces testicular cancer and reduced spermatogenesis and ovarian follicle numbers in mice. PLoS ONE, 9(4):e93311

Drumond, A.L., Weng, C.C., Wang, G., ChiariniGarcia, H., Eras-Garcia, L., Meistrich, M.L. 2011. Effects of multiple doses of cyclophosphamide on mouse testes: accessing the germ cells lost, and the functional damage of stem cells. Reprod. Toxicol, 32:395-406

Drusenheimer, N., Wulf, G., NOLTE, J., LEe, J.H., DEV, A., Dressel, R., Gromoll, J., SchmidTKe, J., ENGeL, W., NAYERNiA, K. 2007. Putative human male germ cells from bone marrow stem cells. Soc. Reprod. Fertil. Suppl. 63: 69-76.

EBATA, KT, YEH, JR, ZHANG, X., NAGANO, M.C. 2008. The application of biomarkers of spermatogonial stem cells for restoring male fertility. Dis Markers, 24:267-276

EBATA, KT, YEH, JR, ZHANG, X., NAGANO, M.C. 2011. Soluble growth factors stimulate spermatogonial stem cell divisions that maintain a stem cell pool and produce progenitors in vitro. Experimental Cell Res., 317(10): 1319-1329

Elangovan, N., Chiou, T.J., Tzeng, W.F., ChU, S.T 2006. Cyclophosphamide treatment causes impairment of sperm and its fertilizing ability in mice. J. Toxicol., 222(1-2): 60-70.

Eliopoulos, N., ZhaO, J., Bouchentouf, M., Forner, K., BIrman, E., YuAn, S., et al. 2010. Human marrow-derived mesenchymal stromal cells decrease cisplatin renotoxicity in vitro and in vivo and enhance survival of mice post intraperitoneal injection. Am J Physiol Renal Physiol., 299: F128898 
EMAdi, A., JONeS, R.J., BRODSKy, R.A., 2009. Cyclophosphamide and cancer: golden anniversary. Nat. Rev. Clin. Oncol., 6: 638-647.

Fazeli, Z., Abedindo, A., OMrani, M.D., GHAderian, S.M.H. 2018. Mesenchymal Stem Cells (MSCs) Therapy for Recovery of Fertility: a Systematic Review. Stem Cell Rev. and Rep. 14: 1-12.

Freireich, E.J., Gehan, E.A., RALl, D.P., SCHMidT, L.H., SKIPPER, H.E. 1986. Quantitative comparison of toxicity of anticancer agents in mouse, rat, hamster, dog, monkey, and man. J. of Cancer Chemother. Rep., 50(14):219-244.

Gerber, J., HeINRICH, J., BREHM, R. 2016. Blood-testis barrier and Sertoli cell function: lessons from SCCX43KO mice, Reprod., 151(2): 15-27.

GHASEMZADEH-HASANKOLAEI M., BATAVANI, R., ESLAMINEJAD MB, SAYAHPOUR F. 2016. Transplantation of Autologous Bone Marrow Mesenchymal Stem Cells into the Testes of Infertile Male Rats and New Germ Cell Formation. Int. J. of Stem Cells, 9 (2): 250-263

GNECCHI, M., MELO, LG, 2009. Bone marrow-derived mesenchymal stem cells: Isolation, expansion, characterization, viral transduction, and production of conditioned medium. Methods Mol. Biol., 482 (18): 281-294

GOU, S., LIU, T., LI, X., CUI, J., WAN, C., WANG, C. 2012. Pancreatic ductal cells acquire mesenchymal characteristics through cell fusion with bone marrowderived mesenchymal stem cells and sirt1 attenuates the apoptosis of hybrid cells. Cells Tissues Organs, 196(36): 129-136

Goddard, I., BoUras, M., Keramidas, M., HeNDRICK, J.C., FEIGE, J.J., BENAHMED, M. 2000. Transforming growth factor-beta receptor types I and II in cultured porcine Leydig cells: expression and hormonal regulation, Endocrinol., 141(6): 2068-74.

Hollenbach, J., Jung, K., Noelke, J., Gasse, H., Pfarrer, C., Koy, M., BREHM, R. 2018. Loss of connexin43 in murine Sertoli cells and its effect on blood-testis barrier formation and dynamics, PLoS One, 1,13(6): e0198100.

Hou, L., Dong, Q., Wu, Y., Sun, Y., Guo, Y., Huo, Y., 2016. Gonadotropins facilitate potential differentiation of human bone marrow mesenchymal stem cells into Leydig cells in vitro. Kaohsing J. Med. Sci., 32: 1-9.

HoWell, S.J., RADFORD, J.A., RYDER, W.D.J., SHALET, S.M. 1999. Testicular function after cytotoxic chemotherapy: evidence of Leydig cell insufficiency. J. clinical oncol., 17(5): 1493-1493.

Hwang, N.S., Zhang, C., Hwang, Y., VArghese, S. 2009. Mesenchymal stem cell differentiation and roles in regenerative medicine. John Wiley Sons, Inc. 1: 97106

Kadam, P., Van Saen, D., Goossens, E. 2017. Can mesenchymal stem cells improve spermatogonial stem cell transplantation efficiency?. Androl., 5(1): 2-9.

Kørbling, M., Estrov, Z., 2003. Adult stem cells for tissue repair - a new therapeutic concept?. N. Engl. J. Med., 349: 570-582.
LEATHERMAN, J. 2013. Stem cells supporting other stem cells. Front. Genet., 4, 257 LUe, Y., ERKKILA, K., LiU, P.Y., MA, K., WANG, C., Hikim, A.S., SwerdlofF, R.S. 2007. Fate of bone marrow stem cells transplanted into the testis: potential implication for men with testicular failure. Am. J. Pathol. 170: 899-908.

MClachlan , R.I., DonNell, L.O., MEACHEM, S.J., Stanton, P.G., Kretser, D.M., Pratis, K., RoBERTSON, D.M. 2002. Identification of specific sites of hormonal regulation in spermatogenesis in rats, monkey and man. J. Recent Prog. Horm. Res., 57: 14-79.

Meyerrose, T.E., De Ugarte, D.A., Hofling, A.A., Herrbrich, P.E., Cordonnier, T.D., Shultz, L.D., et al. 2007. In vivo distribution of human adipose-derived mesenchymal stem cells in novel xenotransplantation models. Stem Cells., 25: 220-7.

MONSEFI, M., FEREYDOUNI, B., ROHANI, L., TALAEI, T. 2013. Mesenchymal stem cells repair germinal cells of seminiferous tubules of sterile rats. Iran. J. Reprod. Med., 11, 537-544

NAYERNIA, K., LEE, J.H., DRUSENHEIMER, N., NOLTE, J., Wulf, G., Dressel, R., Gromoll, J., Engel, W. 2006. Derivation of male germ cells from bone marrow stem cells. Lab Invest, 86: 654-663.

Neosar, 2013. Cyclophosphamide. BC Cancer Agency, Cancer Drug Manual, 1-12.

O'HARA, L., SMITH, L.B. 2015. Androgen receptor roles in spermatogenesis and infertility. Best Pract. Res. Clin. Endocrinol. Metab., 29(4): 595-605.

O'ShaughneSSY, PJ 2014. Hormonal control of germ cell development and spermatogenesis. Semin. Cell Dev. Biol., 29: 55-65.

Peak, T.C., Haney, N.M., Wang, W., DeLay, K.J., Hellstrom, W.J. 2016. Stem cell therapy for the treatment of Leydig cell dysfunction in primary hypogonadism. World j. stem cells, 8(10): 306.

Pourmoghadam, Z., Aghebati-MaleKi, L., Motalebnezhad, M., Yousefi, B., Yousefi, M. 2018. Current approaches for the treatment of male infertility with stem cell therapy. J. cellular physiology, 6455-6469. DOI: 10.1002/jcp.26577.

SarraJ, M.A., Chua, H.K., Umbers, A., Loveland, K.L., FindlaY, J.K., STEnVERS, K.L. 2007. Differential expression of TGFBR3 (betaglycan) in mouse ovary and testis during gonadogenesis. Growth Factors, 25(5): 334-45.

Sarraj, M.A., Escalona, R.M., Umbers, A., Chua, H.K., Small, C., Griswold, M., Loveland, K., FindlaY, J.K. STENVERS, K.L. 2010. Fetal testis dysgenesis and compromised Leydig cell function in Tgfbr3 (beta glycan) knockout mice. Biol. Reprod., 82(1): 153-62.

SNYKers, S., VANhaECKe, T. ANd Rogiers, V. 2006. Isolation of rat bone marrow stem cell. J. of Methods in Mol.Bio., 320:13-18.

SONG, YH, PINKERNELL, K., ALT, E. 2011. Stem cell-induced cardiac regeneration: Fusion/mitochondrial exchange and/or transdifferentiation? Cell Cycle, 10 (37): 2281-2286

Spradling, A., Drummond-BARbOSA, D. KAI, T. 2001. Stem cell finds its niche. Nature, 414: 98-104. 
Sridharan, S., Brehm, R., Bergmann, M., CoOKe, P.S. 2007. Role of connexin 43 in Sertoli cells of testis. Ann. N. Y. Acad. Sci., 1120: 131-43.

Suvarna, K.S., Layton, C., Bancroft, J.D. 2013. Bancroft's Theory and Practice of Histological Techniques. 7th ed. Oxford, Churchill Livingstone Elsevier, 2013. pp.654

Subhan, F., Tahir, F., Ahmad, R., Khan, Z.D. 1995. Oligospermia and its relation with hormonal profile. Pak. Med. Assoc., 45(9): 246- 247.

TAMADON, A., MEHRABANI, D., RAHMANIFAR, F., JAHROMI, AR et al., 2015. Induction of Spermatogenesis by Bone Marrow-derived Mesenchymal Stem Cells in Busulfan-induced Azoospermia in Hamster. Int J Stem Cells, 8: 134-145

TSaI, M.Y., YeH, S.D., WANG, R.S., YEH , S., ZHANG, C., LIN, H.Y., Tzeng, C.R., Chang, C. 2006. Differential effects of spermatogenesis and fertility in mice lacking androgen receptor in individual testis cells. Proc. Natl. Acad. Sci., U S A., 12, 103(50): 18975-80

WALKER, W.H. 2011. Testosterone signaling and the regulation of spermatogenesis. Taylor Fr., 1: 37-41.

Wang, Q., Li, W., Zhang, Y., Yuan, X., Xu, K., Yu, J., Chen, Z., Beroukhim, R., et al., 2009. Androgen Receptor Regulates a Distinct Transcription Program in Androgen-Independent Prostate Cancer. Cell., 138(2): 245-256.

Weinbauer, G.F., LuetJens, C.M., Simoni, M., NiESCHLAG, E. 2010. Physiology of Testicular Function. Springer: 11-59

Weinbauer, G.F., Nieschlag, E. 1995. Gonadotropin control of testicular germ cell development. Adv. Exp. Med. Biol., 317: 55-65.

Wilson, T., Stark, C., Holmbom, J., Rosling, A., et al., 2010. Fate of bone marrow-derived stromal cells after intraperitoneal infusion or implantation into femoral bone defects in the host animal. J Tissue Engineering., 345806.

\section{How to cite this article:}

Ahmed M. Mousbah; Mohamed E. El-Samie; Mohamed A. Elbehery ${ }^{1}$; and Ismail A. El-Nady' 2020. Immunohistochemistry and Hormonal Investigation for Spermatogenesis Restoration in Degenerated Testes of Rats After Bone Marrow Stem Cells Transplantation. Journal of Applied Veterinary Sciences, 5(4): 47 - 54.

DOI: https://dx.doi.org/10.21608/javs.2020.118002
YaZawa, T., MizUtani, T., Yamada, K., KaWata , H., SeKiguChI , T., Yoshino, M., KAJITANI, T., SHOU, Z., UMezawa, A., MiYamoto, K. 2006. Differentiation of adult stem cells derived from bone marrow stroma into Leydig or adrenocortical cells. Endocrinol., 147: 4104-4111.

Yousefi, F., EbTekar, M., Soleimani, M., Soudi, S. HAShemi, S.M. 2013. Comparison of in vivo immunomodulatory effects of intravenous and intraperitoneal administration of adipose-tissue mesenchymal stem cells in experimental autoimmune encephalomyelitis (EAE). Int Immunopharmacol., 17:608-16.

Zabul, J., MierzeJewski, W., Rogoza, A. 1994. Usefulness of examining gonadotropin hormones and testosterone in men with abnormal semen. Ginekolpol., 65 (2): 71-74.

ZahKOOK, S.A., ATWA, A., Shahat, M., Mansour, A.M., BAKRY, S. 2014. Mesenchymal stem cells restore fertility in induced azoospermic rats following chemotherapy administration. J. Reprod. Infertil., 5: 50-57.

ZHANG, D., LIU, X., PENG, J., HE, D., LIN, T., ZHU, J., LI, X., ZHANG, Y., WEI, G. 2014. Potential spermatogenesis recovery with bone marrow mesenchymal stem cells in an azoospermic rat model. Int J Mol Sci., 15:13151-13165

Zhu, B., Zheng, Y.F., Zhang, Y.Y., CaO, Y.S., Zhang, L., LI, X. G., ZHAO, Z. G. 2015. Protective effect of L-carnitine in cyclophosphamide-induced germ cell apoptosis. J. Zhejiang Univ. Sci., B., 16(9): 780-787. 